\title{
Pengaruh Current Ratio, Debt To Equity Ratio dan Return On Equity Terhadap Harga Saham (Studi Pada PT. Lippo Cikarang, Tbk Periode 2014-2019)
}

\author{
Finti Arista1; Anwar Musadad² \\ 1) Prodi Manajemen Fakultas Ekonomi, Universitas Singaperbangsa Karawang \\ email : finti.arista16152@student.unsika.ac.id; anwarsadad21febunsika@gmail.com
}

\section{ARTICLES INFORMATION}

\begin{tabular}{cc} 
ARTICLES & ABSTRACT \\
INFORMATION & \\
\hline
\end{tabular}

\section{JURNAL SEKURITAS \\ (Saham, Ekonomi, Keuangan dan Investasi ) \\ Vol.4, No.1, September 2020 Halaman : $57-67$ \\ (c) LPPM \& Prodi Manajemen UNVERSITAS PAMULANG \\ ISSN (online) : 2581-2777 ISSN (print) : : 2581-2696 \\ Keyword : \\ Current Ratio; Debt to Equity Ratio; Return On Equity; Harga Saham}

JEL. classification :

C33, G21, G24, N15, N25

\section{Contact Author :}

PRODI MANAJEMEN UNPAM

JL.Surya Kencana No.1 Pamulang

Tangerang Selatan - Banten

Telp. (021) 7412566, Fax (021)

7412491

Email :

sekuritas@unpam.ac.id
Penelitian dilakukan dengan menggunakan metode deskriptif dan verifikatif, yaitu: mengumpulkan, menyajikan, menganalisis, dan melakukan pengujian hipotesis, serta membuat kesimpulan dan saran. Sampel dikumpulkan menggunakan metode Purposive Sampling menggunakan 24 data keuangan dari laporan keuangan PT. Lippo Cikarang, Tbk dari selama periode 2014-2019. Teknik analisis data menggunakan teknik Analisis Regresi Linier Berganda dan Analisis Koefisien Determinasi. Adapun hasil penelitian menyatakan bahwa CR, DER dan ROE berpengaruh terhadap Harga Saham PT. Lippo Cikarang, Tbk selama periode $2014-2019$ sebesar $61,8 \%$.

Research is conducted using descriptive and verifiative methods, namely: collecting, presenting, analyzing, and conducting hypothetical testing, as well as making conclusions and suggestions. Samples were collected using purposive sampling method using 24 financial data from PT financial statements. Lippo Cikarang, Tbk from 2014-2019. Data analysis techniques using Multiple Linear Regression Analysis techniques and Determination Coefficient Analysis. The results of the study stated that CR, DER and ROE affect the Share Price of PT. Lippo Cikarang, Tbk during the period 2014-2019 amounted to $61.8 \%$. 


\section{A. PENDAHULUAN}

Harga saham merupakan penentu untuk para investor menginvestasikan dananya di pasar modal, jika nilai harga saham tinggi maka akan mencerminkan tingkat pengembalian modal yang efektif dan mendatangkan keuntungan. Efek yang sering terjadi di pasar modal ialah harga saham yang selalu mengalami fluktuasi. Hal ini menjadikan investor lebih cermat dalam memilih saham untuk nilai jual dimasa yang akan datang.(Feri, 2014:1526)

PT. Lippo Cikarang, Tbk merupakan perusahaan sektor bisnis properti yang banyak diminati investor asing khususnya dari negara AS, Inggris, Singapura dan Tiongkok untuk saling bekerjasama dalam pembangunan proyek Meikarta. Total nilai investasi dalam kerjasama tersebut mencapai 300 juta dollar AS atau sekitar 278 triliun rupiah. (sumber: kompas.com, diakses 19-09-2019 pukul 23.31)

Perkembangan bisnis properti perusahaan Lippo Cikarang (LPCK) pada tahun 2014 sampai 2018 dapat dibilang mengalami fluktuasi. Hal ini terjadi pada perubahan harga saham perusahaan yang terus mengalami kenaikan dan penurunan secara signifikan pada tiap tahunnya.

Tabel 1.1

Harga Saham PT. Lippo Cikarang, Tbk Tahun 2014-2019

\begin{tabular}{|c|c|c|c|c|}
\multicolumn{4}{c}{ (dalam Rupiah) } \\
\hline \multirow{2}{*}{ Periode } & \multicolumn{4}{|c|}{ Harga Saham / Triwulan } \\
\cline { 2 - 5 } & $\mathbf{1}$ & $\mathbf{2}$ & $\mathbf{3}$ & $\mathbf{4}$ \\
\hline $\mathbf{2 0 1 4}$ & 8075 & 8500 & 8600 & 10800 \\
\hline $\mathbf{2 0 1 5}$ & 11675 & 9100 & 6675 & 7250 \\
\hline $\mathbf{2 0 1 6}$ & 7075 & 7750 & 5875 & 5050 \\
\hline $\mathbf{2 0 1 7}$ & 4250 & 4110 & 4180 & 3140 \\
\hline $\mathbf{2 0 1 8}$ & 3100 & 1790 & 1820 & 1475 \\
\hline $\mathbf{2 0 1 9}$ & 1850 & 1505 & 1220 & 1015 \\
\hline
\end{tabular}

Dalam menilai perkembangan harga saham yang baik dapat diukur melalui analisis rasio keuangan. Tujuan analisis rasio keuangan adalah untuk membantu perusahaan dalam mengidentifikasi kekuatan dan kelemahan manajemen perusahaan dalam memberdayakan seluruh sumber daya yang ada untuk mencapai target yang ditetapkan oleh kebijakan pendiri perusahaan tersebut. (Sujarweni, 2017)

Rasio keuangan sering disebut sebagai faktor fundamental perusahaan. Bagi semua perusahaan go public wajib melampirkan rasio keuangan sesuai dengan peraturan yang telah ditetapkan Bapepam KEP-51/PM/1997 tentang pedoman bentuk dan isi prospektus dalam rangka penawaran umum efek beragun aset.

Adapun penelitian ini bertujuan untuk mengetahui, menganalisis dan menjelaskan pengaruh dari variabel dependen yaitu harga saham dengan variabel independen rasio keuangan yang dibatasi pada Current Ratio, Debt to Equity Ratio dan Return On Equity.

Berdasarkan uraian di atas, maka rumusan masalah dalam penelitian ini yaitu:

1. Bagaimana pengaruh Current Ratio, Debt to Equity Ratio dan Return On Equity secara parsial terhadap Harga Saham di PT. Lippo Cikarang selama periode 2014-2019?

2. Bagaimana pengaruh Current Ratio, Debt to Equity Ratio dan Return On Equity secara simultan terhadap Harga Saham di PT. Lippo Cikarang selama periode 2014-2019? 


\section{B. KAJIAN LITERATUR}

\section{Harga Saham}

Menurut Darmadji dan Fakhruddin (2012:102), Harga saham adalah harga yang terjadi di bursa pada waktu tertentu. Harga saham bisa berubah naik atau pun turun dalam hitungan waktu begitu cepat. la dapat berubah dalam hitungan menit bahkan dapat berubah dalam hitungan detik. Hal tersebut dimungkinkan karena tergantung dengan permintaan dan penawaran antara pembeli saham dengan penjual saham. Salah satu konsep dasar dalam manajemen keuangan yaitu mencapai tujuan dengan memaksimalisasi nilai perusahaan. Bagi perusahaan yang telah go public, tujuan tersebut dapat dicapai dengan cara memaksimalisasi nilai pasar harga saham yang bersangkutan. Dengan demikian pengambilan keputusan selalu didasarkan pada pertimbangan terhadap maksimalisasi kekayaan para pemegang saham. Harga saham merupakan harga penutupan pasar saham selama periode pengamatan untuk tiap-tiap jenis saham yang dijadikan sampel dan pergerakannya senantiasa diamati oleh para investor.

Berdasarkan fatwa dewan syariah nasional nomor 8 tahun 2011 dijelaskan pada ketentuan umum pertama ayat 7 bahwa harga pasar wajar adalah harga pasar dari efek bersifat ekuitas sesuai prinsip syariah yang sesuai dengan mekanisme pasar yang teratur, wajar dan efisien serta tidak direkayasa.Harga saham adalah harga yang terjadi di pasar bursa pada saat tertentu yang ditentukan oleh pelaku pasar dan ditentukan oleh permintaan dan penawaran saham yang bersangkutan di pasar modal.(Jogiyanto, 2008)

\section{Current Ratio (CR)}

Perhitungan rasio lancar dilakukan dengan cara membandingkan antara total aktiva lancar dengan total utang lancar. Rumus untuk menghitung rasio lancar atau current ratio yaitu:

$$
\text { Current Ratio }=\frac{\text { Aktiva Lancar }}{\text { Hutang Lancar }} \times 100 \%
$$

Dari hasil pengukurusan rasio, apabila rasio lancar rendah maka dapat dikatakan bahwa perusahaan kurang modal untuk membayar utang. Namun, apabila hasil pengukuran rasio tinggi, belum tentu kondisi perusahaan sedang baik. Hal ini dapat saja terjadi karena kas tidak digunakan sebaik mungkin. Menurut Harahap (2007:301), "Apabila rasio lancar 1:1 atau $100 \%$ berarti bahwa aktiva lancar dapat menutupi semua hutang lancar. Jadi dikatakan sehat jika rasionya berada di atas 1 atau diatas 100\%. Artinya aktiva lancar harus jauh di atas jumlah hutang lancar."

\section{Debt to Equity Ratio (DER)}

Rasio ini berguna untuk mengetahui jumlah dana yang disediakan peminjam (kreditor) dengan pemilik perusahaan. Menurut Joel G. Siegel dan Jae K. Shim mendefinisikannya sebagai ukuran yang dipakai dalam menganalisis laporan keuangan untuk memperlihatkan besarnya jaminan yang tersedia untuk kreditor.(Fahmi, 2011:128). Adapun rumus untuk menghitung debt to equity ratio yaitu:

$$
\text { Debt to Equity Ratio }=\frac{\text { Total Hutang }}{\text { Ekuitas }}
$$

Dari hasil pengukurusan rasio, menurut Sutrisno (2013:224) bahwa "Semakin tinggi rasio ini berarti modal sendiri semakin sedikit disbanding dengan hutangnya. Bagi perusahaan, sebaiknya besarnya hutang tidak boleh melebihi modal sendiri agar beban tetapnya tidak 
terlalu tinggi. Untuk pendekatan konservatif besarnya hutang maksimal sama dengan modal sendiri, artinya debt to equity-nya maksimal 100\%."

\section{Return On Equity (ROE)}

Menurut Kasmir (2012:204) menjelaskan bahwa, Return on equity atau rentabilitas modal merupakan rasio untuk mengukur laba bersih sesudah pajak dengan modal sendiri. Rasio ini menunjukkan efisiensi penggunaan modal sendiri. Semakin tinggi rasio ini, maka semakin baik. Artinya posisi pemilik perusahaan semakin kuat, demikian pula sebaliknya. Untuk menghitung ROE menggunakan rumus:

$$
R O E=\frac{E A T}{\text { Total Ekuitas }}
$$

Dari hasil pengukuran rasio, nilai ROE yang tinggi akan meningkatkan harga saham dan akan menarik para investor untuk menanamkan modalnya pada perusahaan sehingga akan terjadi pengaruh positif antara profitabilitas dengan harga saham, dimana tingginya harga saham tersebut tentu akan meningkatkan nilai perusahaan.

\section{METODOLOGI PENELITIAN}

Pada penelitian ini menggunakan metode kuantitatif karena data yang diambil bersifat statistik berdasarkan angka-angka yang tertera pada laporan keuangan PT. Lippo Cikarang, Tbk dengan tujuan untuk menguji seberapa besar pengaruh current ratio, debt to equity ratio dan return on equity terhadap Harga Saham perusahaan tersebut.

Pendekatan deskriptif menurut Sugiyono (2017:35) dilakukan mengetahui nilai variabel mandiri satu variabel atau lebih (independen) tanpa membuat pembanding atau hubungan dengan variabel lain. Secara deskriptif penelitian ini bertujuan untuk memperoleh gambaran tentang current ratio, debt to equity ratio dan return on equity sebagai variabel independen atau variabel bebas dan Harga Saham sebagai variabel dependen atau variabel terikat.

Populasi yang digunakan dalam penelitian ini adalah laporan keuangan PT. Lippo Cikarang, Tbk. selama periode 2014-2019 sebanyak 24 data. Teknik sampling yang digunakan dalam penelitian ini adalah nonprobility sampling. Teknik penarikan sampel pada penelitian ini menggunakan purposive sampling. Penelitian ini menggunakan model regresi linear OLS (Ordinary Least Square) melalui uji asumsi klasik sebagai penentu keabsahan data valid atau tidak valid dari variabel-variabel yang akan diteliti dan teknik analisis data yang digunakan yaitu teknik analisis regresi linier berganda dan analisis koefisien determinasi dengan bantuan Mehtodof Successive Interval (MSI), program komputer Microsoft Excel 2013, dan SPSS versi 16. 


\section{HASIL DAN PEMBAHASAN}

1. Uji Asumsi Klasik

a. Uji Normalitas

Tabel 4.1

Hasil Uji Normalitas

\begin{tabular}{llr}
\hline \multicolumn{2}{c}{ One-Sample Kolmogorov-Smirnov Test } \\
\hline & & $\begin{array}{c}\text { Unstandardized } \\
\text { Residual }\end{array}$ \\
\hline $\mathrm{N}$ & Mean & 24 \\
Normal & Std. Deviation & .0000000 \\
Parameters & \\
Most Extreme & Absolute & $.87217940 \mathrm{E} 3$ \\
Differences & Positive & .182 \\
& Negative & .182 \\
Kolmogorov-Smirnov Z & .104 \\
Asymp. Sig. (2-tailed) & .890 \\
\hline a. Test distribution is Normal. & .406 \\
\multicolumn{2}{c}{ (sumber: Output SPSS 16, 2020) }
\end{tabular}

Tabel 4.1 menunjukkan bahwa nilai Asymp. Sig sebesar 0,406 lebih besar dari nilai signifikansi 0,05 artinya data pada variabel CR, DER dan ROE terhadap Harga Saham PT. Lippo Cikarang, Tbk periode 2014-2019 hasilnya berdistribusi normal dan model regresi linier pada uji (K-S) memenuhi asumsi normalitas.

b. Uji Heterokedastisitas

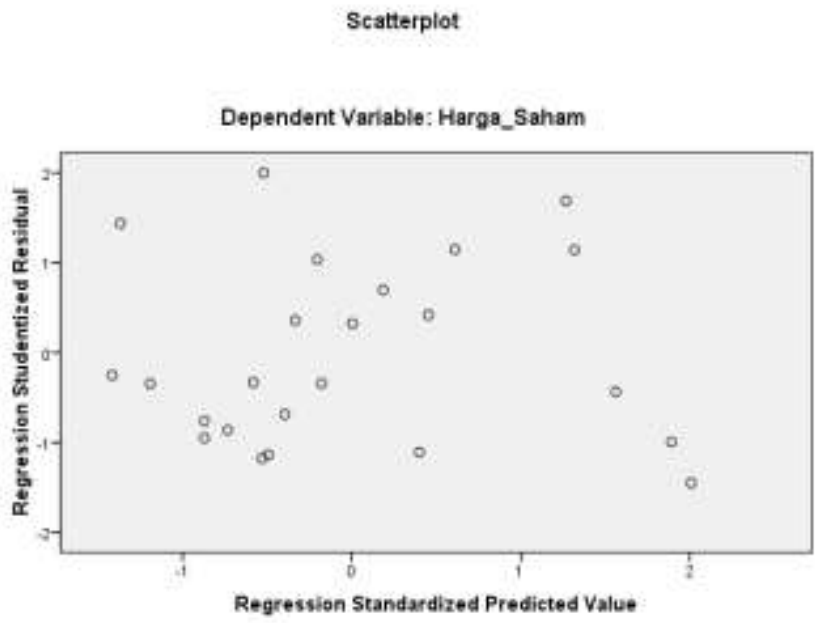

Gambar 4.1 Grafik Scatterplot

(sumber: Output SPSS 16, 2020)

Gambar 4.1 di atas menunjukkan bahwa titik-titik menyebar secara acak dan tersebar di atas maupun di bawah angka 0 pada sumbu Y. Hal ini menyimpulkan bahwa hasil data tidak terjadi heteroskedastisitas pada model regresi, sehingga model regresi layak dipakai untuk memprediksi Harga Saham pada perusahaan 
c. Uji Multikolinearitas

Tabel 4.2

Hasil Uji Multikolinearitas

\begin{tabular}{cccc}
\hline \multicolumn{4}{c}{ Coefficients $^{\mathrm{a}}$} \\
\hline \multicolumn{3}{c}{ Model } & \multicolumn{2}{c}{ Collinearity Statistics } \\
\cline { 3 - 4 } & & Tolerance & VIF \\
\hline 1 & (Constant) & & \\
& CR & .282 & 3.541 \\
& DER & .315 & 3.178 \\
& ROE & .797 & 1.255 \\
\hline
\end{tabular}

a. Dependent Variable: Harga_Saham

(sumber: Output SPSS 16, 2020)

Berdasarkan pada tabel 4.2 di atas dapat dijelaskan beberapa kesimpulan antara lain:

1. Nilai Tolerance untuk variabel Current Ratio $\left(X_{1}\right)$ sebesar $0.282>0.10$ dan nilai VIF sebesar $3.541<10$, sehingga variabel Current Ratio dinyatakan tidak terjadi gejala multikolinieritas.

2. Nilai Tolerance untuk variabel Debt to Equity Ratio $\left(X_{2}\right)$ sebesar $0.315>0.10$ dan nilai VIF sebesar $3.178<10$, sehingga variabel Debt to Equity Ratio dinyatakan tidak terjadi gejala multikolinieritas.

3. Nilai Tolerance untuk variabel Return On Equity $\left(X_{3}\right)$ sebesar $0.797>0.10$ dan nilai VIF sebesar $1.255<10$, sehingga variabel Return On Equity dinyatakan tidak terjadi gejala multikolinieritas.

d. Uji Autokorelasi

Tabel 4.3

Hasil Uji RunTest

\begin{tabular}{lr}
\hline \multicolumn{2}{c}{ Runs Test } \\
\hline & $\begin{array}{c}\text { Unstandardize } \\
\text { d Residual }\end{array}$ \\
\hline Test Value $^{\text {a }}$ & -578.03458 \\
Cases < Test Value & 12 \\
Cases >= Test Value & 12 \\
Total Cases & 24 \\
Number of Runs & 6 \\
Z & -2.713 \\
Asymp. Sig. (2-tailed) & .007 \\
\hline a. Median \\
(sumber: Output SPSs 16, 2020)
\end{tabular}

Berdasarkan tabel 4.3 di atas dapat dilihat bahwa nilai Asymp. Sig yakni 0,07 >0,05 maka kesimpulannya tidak terjadi autokorelasi pada residual data antar variabel. 
2. Hasil Analisis Data

a. Hasil Statistik Deskriptif

Tabel 4.4

Hasil Statistik Deskriptif

\begin{tabular}{cccccc}
\hline & N & Minimum & Maximum & Mean & $\begin{array}{c}\text { Std. } \\
\text { Deviation }\end{array}$ \\
\hline CR & 24 & 1.91 & 6.68 & 4.5557 & 1.43731 \\
DER & 24 & .12 & .91 & .4451 & .21540 \\
ROE & 24 & .01 & .38 & .1432 & .11716 \\
Harga_Saham & 24 & 1015 & 11675 & 5245.00 & 3250.284 \\
\hline Valid N & 24 & & & & \\
(listwise) & & & & &
\end{tabular}

(Sumber: Output SPSS 16, 2020)

Berdasarkan tabel 4.4 di atas dapat disimpulkan bahwa:

1. Variabel Harga Saham (Y) diperoleh nilai tertinggi sebesar Rp. 11.675 dan nilai terendah sebesar Rp. 1015. Selain itu juga didapatkan nilai mean (M) sebesar Rp. 5245,00, serta standar deviasi (SD) sebesar 3250,284.

2. Variabel Current Ratio diperoleh nilai terendah sebesar 1,91 atau $191 \%$ dan nilai tertinggi sebesar 6,68 atau $668 \%$. Selain itu, nilai mean sebesar 4,57 atau $457 \%$ dan standar deviasi (SD) sebesar 1,43731

3. Variabel Debt to Equity Ratio diperoleh nilai terendah sebesar 0,12 atau $12 \%$ dan nilai tertinggi sebesar 0,91 atau $91 \%$. Selain itu, nilai mean sebesar 0,44 atau $44 \%$ dan standar deviasi (SD) sebesar 0,21540

4. Variabel Return On Equity diperoleh nilai terendah sebesar 0,01 atau $1 \%$ dan nilai tertinggi sebesar 0,38 atau $38 \%$. Selain itu, nilai mean sebesar 0,14 atau $14 \%$ dan standar deviasi (SD) sebesar 0,11716

b. Regresi Linier Berganda

Tabel 4.5

Hasil Uji Regresi Berganda

\begin{tabular}{llccc}
\hline \multicolumn{4}{c}{ Coefficients $^{\mathrm{a}}$} \\
\hline \multirow{2}{*}{ Model } & \multicolumn{2}{c}{$\begin{array}{c}\text { Unstandardized } \\
\text { Coefficients }\end{array}$} & $\begin{array}{c}\text { Standardized } \\
\text { Coefficients }\end{array}$ \\
\cline { 3 - 5 } & & $\mathrm{B}$ & Std. Error & Beta \\
\hline 1 & (Constant) & 12627.329 & 4162.223 & \\
& CR & -1698.873 & 548.060 & -.751 \\
& DER & 1637.607 & 3464.985 & .109 \\
& ROE & -2594.864 & 4002.403 & -.094 \\
\hline
\end{tabular}

a. Dependent Variable: Harga_Saham

Jurnal SEKURITAS (Saham, Ekonomi, Keuangan dan Investasi ), Vol.4, No.1, September 2020 ....63 
Hasil nilai konstata dan koefisien regresi dari tabe 4.5 dapat dirumuskan sebagai berikut:

$\mathrm{Y}=\mathrm{a}+\mathrm{b} 1 \mathrm{X} 1+\mathrm{b} 2 \mathrm{X} 2+\mathrm{b} 3 \mathrm{X} 3+\mathrm{e}$

Keterangan:

Y : Harga Saham

a : konstanta

b : Unstandardized Coefficients B

$\mathrm{X} 1: \mathrm{CR}$

$\mathrm{X} 2$ : DER

X3 : ROE

e : Std. Error

Harga Saham $=12627.329-1698.873 C R+1637.607 D E R-2594.864 R O E+4162.223$

Dari persamaan regresi linier berganda di atas dapat dijelaskan sebagai berikut:

a) Konstanta (a)

Nilai konstanta (a) memperoleh nilai sebesar 12627.329 dapat diartikan jika Current Ratio, Debt to Equity Ratio dan Return On Equity nilainya 0, maka harga saham nilainya sebesar 12627.329

b) Koefisien Current Ratio (X1)

Nilai koefisien regresi linier berganda pada variable CR adalah variable sebesar 1698.873. Hal ini menunjukkan adanya hubungan varibel CR dengan Harga Saham artinya apabila Current Ratio turun sebesar 1 satuan, maka Harga Saham akan menurun juga sebesar -1698.873 dan begitupun sebaliknya.

c) Koefisien Debt to Equity Ratio (X2)

Nilai koefisien regresi linier berganda pada variable DER adalah positif sebesar 1637.607. Hal ini menunjukkan adanya hubungan positif atau searah variable DER dengan Harga Saham artinya jika Debt to Equity Ratio berubah naik 1 satuan maka Harga Saham akan meningkat sebesar 1637.607.

d) Koefisien Return On Equity (X3)

Nilai koefisien regresi linier berganda pada variable ROE adalah ariable sebesar 2594.864. Hal ini menunjukkan adanya hubungan variabel ROE dengan Harga Saham artinya apabila Return On Equity turun sebesar 1 satuan, maka Harga Saham akan menurun juga sebesar -2594.864 dan begitupun sebaliknya.

c. Koefisien Determinasi

Tabel 4.6

Hasil Uji Koefisien Determinasi

\begin{tabular}{|c|c|c|c|c|}
\hline \multicolumn{5}{|c|}{ Model Summary ${ }^{b}$} \\
\hline $\begin{array}{l}\text { Mode } \\
\text { I }\end{array}$ & $\mathrm{R}$ & R Square & $\begin{array}{l}\text { Adjusted R } \\
\text { Square }\end{array}$ & $\begin{array}{l}\text { Std. Error of } \\
\text { the Estimate }\end{array}$ \\
\hline 1 & $.817^{\mathrm{a}}$ & 668 & .618 & 2007.689 \\
\hline
\end{tabular}

a. Predictors: (Constant), ROE, DER, CR

b. Dependent Variable: Harga_Saham

(Sumber: Output SPSS 16, 2020) 
Berdasarkan hasil perhitungan koefisien determinasi pada tabel 4.6 di atas diketahui pengaruh ketiga variabel CR, DER dan ROE terhadap Harga Saham PT. Lippo Cikarang selama periode 2014-2019 yang dinyatakan dengan nilai Adjusted R Square memperoleh nilai sebesar 0,618 atau $61,8 \%$. Hal ini menunjukkan bahwa $61,8 \%$ variasi Harga Saham berpengaruh simultan dari ketiga variabel independen yaitu Current Ratio (CR), Debt to Equity Ratio (DER) dan Return On Equity (ROE), sedangkan sisanya 38,2\% dapat dijelaskan oleh sebab-sebab lain di luar model regresi atau variabel independen lainnya yang tidak termasuk dalam penelitian ini yang mempengaruhi variabel Harga Saham.

3. Hasil Pengujian Hipotesis

a. Hasil Uji Parsial (Uji-T)

Tabel 4.7

Hasil Uji Parsial

\begin{tabular}{|c|c|c|c|c|c|c|}
\hline \multicolumn{7}{|c|}{ Coefficients $^{a}$} \\
\hline \multirow[t]{2}{*}{ Model } & & \multicolumn{2}{|c|}{ Unstandardized Coefficients } & \multirow{2}{*}{$\begin{array}{c}\text { Standardized } \\
\text { Coefficients } \\
\text { Beta } \\
\end{array}$} & \multirow[t]{2}{*}{$\mathrm{t}$} & \multirow[t]{2}{*}{ Sig. } \\
\hline & & B & Std. Error & & & \\
\hline \multirow[t]{4}{*}{1} & (Constant) & 12627.329 & 4162.223 & & 3.034 & .007 \\
\hline & $\mathrm{CR}$ & -1698.873 & 548.060 & -.751 & -3.100 & .006 \\
\hline & DER & 1637.607 & 3464.985 & .109 & .473 & .642 \\
\hline & ROE & -2594.864 & 4002.403 & -.094 & -.648 & .524 \\
\hline
\end{tabular}

a. Dependent Variable: Harga_Saham

(Sumber: Output SPSS 16, 2020)

b. Hasil Uji Simultan (Uji F)

Tabel 4.8

Hasil Uji Simultan

\begin{tabular}{lrrrrrr}
\hline \multicolumn{7}{c}{ ANOVA $^{\mathrm{b}}$} \\
\hline \multicolumn{1}{l}{ Model } & Sum of Squares & df & Mean Square & F & \multirow{2}{*}{ Sig. } \\
\hline 1 & Regression & 1.6248 & 3 & 5.4127 & 13.427 & $.000^{\mathrm{a}}$ \\
& Residual & 8.0627 & 20 & 4030814.067 & & \\
& Total & 2.4308 & 23 & & & \\
\hline
\end{tabular}

a. Predictors: (Constant), ROE, DER, CR

b. Dependent Variable: Harga_Saham

(Sumber: Output SPSS 16, 2020)

\section{Pembahasan}

\section{Pembahasan Deskriptif}

Pada penelitian ini, variabel independen yang digunakan adalah Current Ratio (X1), Debt to Equity Ratio (X2) dan Return On Equity (X3) sedangkan variabel dependen yang digunakan adalah Harga Saham (Y). Sampel yang digunakan untuk penelitian ini Jurnal SEKURITAS (Saham, Ekonomi, Keuangan dan Investasi ), Vol.4, No.1, September 2020 ....65 
adalah sebanyak 24 data yang didapat dari laporan keuangan PT. Lippo Cikarang, Tbk tahun 2014-2019. Adapun hasil pembahasan dengan metode deskripsi dari masingmasing variabel dalam penelitian deskriptif dikatakan sehat dan baik.

\section{Pembahasan Verifikatif}

a. Hasil Pembahasan Secara Parsial Variabel Current Ratio (X1), Debt to Equity Ratio (X2) dan Return On Equity (X3) terhadap Harga Saham (Y) Dalam penelitian ini variabel Current Ratio (X1) dan Debt to Equity Ratio (X2) berpengaruh signifikan terhadap Harga Saham (Y) sedangkan variabel Return On Equity (X3) tidak berpengaruh signifikan terhadap Harga Saham (Y).

b. Hasil Pembahasan Secara Simultan Variabel Current Ratio (X1), Debt to Equity Ratio (X2) dan Return On Equity (X3) terhadap Harga Saham (Y)

Hasil pengujian hipotesis secara simultan menunjukkan bahwa variabel Current Ratio (CR), Debt to Equity Ratio (DER) dan Return On Equity (ROE) terdapat pengaruh positif dan signifikan terhadap variabel Harga Saham pada PT. Lippo Cikarang, Tbk selama periode 2014-2019.

\section{E. KESIMPULAN}

Berdasarkan hasil penelitian, pengolahan data dan diskusi yang telah dilakukan maka kesimpulan yang dapat diambil mengenai Current Ratio, Debt to Equity Ratio dan Return On Equity atas Harga Saham PT. Lippo Cikarang, Tbk selama periode 2014-2019 berdasarkan formulasi permasalahan yang telah dibuat adalah sebagai berikut:

1. Sesuai dengan Peraturan OJK Nomor 1/SEOJK.05/2016 tentang tingkat kesehatan keuangan perusahaan pembiayaan, variabel Current Ratio, Debt to Equity Ratio dan Return On Equity memperoleh nilai rata-rata $4,57 \%, 44,5 \%$ dan $14,3 \%$ yang berarti rasio perusahaan dapat dikatakan aman, sangat baik dan sehat secara finansial

2. Berdasarkan pengujian parsial, hasil pada variabel CR negatif pada $17,8 \%$, DER positif pada $16,6 \%$ dan ROE negatif pada $25,8 \%$. Artinya, ada hubungan yang kuat antara variabel indepeden dan Harga Saham PT. Lippo Cikarang, Tbk selama periode 2014-2019.

3. Berdasarkan pengujian simultan terdapat pengaruh antara $C R$, DER dan ROE terhadap Harga Saham PT. Lippo Cikarang, Tbk selama periode 2014-2019 sebesar 61,8\%, sedangkan $38,2 \%$ sisanya merupakan pengaruh variabel lain yang tidak diteiti.

\section{DAFTAR PUSTAKA}

Azmy, A., dan Lestari, A. (2019). Analisis Pengaruh Rasio Keuangan Terhadap Harga Saham Perusahaan RE \& Properti di Indonesia. Jurnal Riset Manajemen Sains Indonesia (JRMSI). Sekolah Bisnis Manajemen. Universitas Tanri Abeng.

Darmadji, T dan Fakhrudin, M.H. 2011. Pasar Modal di Indonesia Pendekatan Tanya Jawab. Edisi 3. Jakarta: Salemba Empat

Fahmi, Irham. 2011. Analisis Laporan Keuangan. Cetakan Ke-6. Bandung: Alfabeta 
Feri, M. 2014. Pengaruh Rasio Profitabilitas Terhadap Perubahan Harga Saham Pada Perusahaan Sektor Properti Yang Listing di Bursa Efek Indonesia Periode 2008-2012. Jurnal IImu Manajemen. Fakultas Ekonomi Universitas Negeri Surabaya.

Fransiska. (2017). Kinerja Keuangan Dengan Menggunaka Rasio Finansial Pada PT Lippo Cikarang, Tbk. dan Entitas Anak. Jurnal Akuntansi Keuangan. STIE Widya Dharma Pontianak.

Harahap, Sofyan Syari. 2010. Analisis Kritis Atas Laporan Keuangan. Edisi 1. Jakarta : Rajawali Pers

Indonesia (1995). Undang-Undang No. 8 Tahun 1995 tentang Pasar Modal. Jakarta: Menteri Keuangan.

Indonesia (2015). POJK No. 15 Tahun 2015 tentang Penerapan Prinsip Syariah di Pasar Modal

Indonesia (2018). Fatwa Dewan Syari'ah Nasional No. 80 Tahun 2018 tentang Penerapan Prinsip Syariah Dalam Mekanisme Perdagangan Efek Bersifat Ekuitas di Pasar Reguler Bursa Efek

Jogiyanto. 2008. Teori Portofolio dan Analisis Investasi. Edisi Ketiga. Yogyakarta: BPFE

Kasmir. 2012. Analisis Laporan Keuangan. Edisi Revisi. Jakarta: Rajawali Pers

Sugiyono. 2010. Metode Penelitian Kuantitatif, Kualitatif, dan R\&D. Bandung: Alfabeta

Sunardi, N. (2019). Profitabilitas, Likuiditas, Dan Multiplier Equity Pengaruhnya Terhadap Harga Serta Return Saham Pada Industri Manufaktur Tahun 20122017. INOVASI, 6(1), 58-73.

Sunardi, N. (2019). Relevansi Intelectual Capital terhadap Harga dan Retun Saham di Industri Perbankan Pemerintah di Indonesia. JIMF (Jurnal IImiah Manajemen Forkamma), 3(1).

Sutrisno. 2013. Manajemen Keuangan Teori Konsep \& Aplikasi. Yogyakarta: Ekonisia

Wijayanto, Dian. 2012. Pengantar Manajemen. Jakarta : Gramedia Pustaka Utama

Annual Report Lippo Cikarang (LPCK). Retrieved from http://lippo-cikarang.com/investor/ https://www.idx.co.id/

https://www.ojk.go.id/Default.aspx

https://www.liputan6.com/

https://money.kompas.com/

https://tirto.id/

https://id.investing.com/ 